\title{
"Prospects for the innovative development of information technology in Ukraine during economic crisis"
}

\begin{tabular}{|c|c|}
\hline AUTHORS & $\begin{array}{l}\text { Sergiy Frolov } \mathbb{D} \text { https://orcid.org/0000-0001-9374-7274 } \\
\mathbb{R} \text { http://www.researcherid.com/rid/C-1635-2018 } \\
\text { Anastasiia Hovorun } \\
\text { Myroslav Ostapenko }\end{array}$ \\
\hline ARTICLE INFO & $\begin{array}{l}\text { Sergiy Frolov, Anastasiia Hovorun and Myroslav Ostapenko (2017). Prospects } \\
\text { for the innovative development of information technology in Ukraine during } \\
\text { economic crisis. Innovative Marketing , 13(1), 55-60. } \\
\text { doi:10.21511/im.13(1).2017.05 }\end{array}$ \\
\hline DOI & http://dx.doi.org/10.21511/im.13(1).2017.05 \\
\hline RELEASED ON & Thursday, 25 May 2017 \\
\hline RECEIVED ON & Thursday, 04 May 2017 \\
\hline ACCEPTED ON & Tuesday, 23 May 2017 \\
\hline LICENSE & $\begin{array}{l}(c) E Y \\
\text { This work is licensed under a Creative Commons Attribution } 4.0 \text { International } \\
\text { License }\end{array}$ \\
\hline JOURNAL & "Innovative Marketing " \\
\hline ISSN PRINT & $1814-2427$ \\
\hline ISSN ONLINE & $1816-6326$ \\
\hline PUBLISHER & LLC “Consulting Publishing Company "Business Perspectives" \\
\hline FOUNDER & LLC "Consulting Publishing Company "Business Perspectives" \\
\hline
\end{tabular}

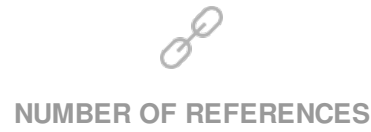

18

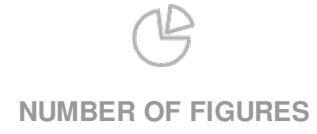

7
NUMBER OF TABLES

3

(C) The author(s) 2023. This publication is an open access article. 


\title{
Sergiy Frolov (Ukraine), Anastasiia Hovorun (Ukraine), Myroslav Ostapenko (Ukraine) Prospects for the innovative development of information technology in Ukraine during economic crisis
}

\begin{abstract}
Information technology is characterized by an increasing pace of development, a high level of innovation and an increasing share in the GDP of most countries. Similar tendencies are inherent in Ukraine. But it should be noted that the economic crisis in the country began in 2014 and the historical conditions of development cause a number of problems that slow down development and create barriers for the integration of the Ukrainian IT market with the world market. The article analyzes the current situation of information technology in Ukraine as the leading innovative industry and identifies the main system problems, as well as industry trends, and suggests solutions to enhance the international competitiveness of the country.

Forecasts were created using extrapolation polynomial trendline construction models and by the construction of an artificial neural network. Based on actual and predicted values of the IT market volumes, the authors estimated the level of its future development using taxonomic analysis. The results enable interested parties to determine the risks and increase the effectiveness of management decisions in IT field.
\end{abstract}

Keywords: information technology, information and communication technology industry, innovations.

JEL Classification: G17, M15, O11.

Received on: $4^{\text {th }}$ of May, 2017.

Accepted on: $23^{\mathrm{d}}$ of May, 2017.

Introduction

In the time of globalization, the top level of innovative industries in Ukraine is the information technology industry. This is especially significant, because it creates a very positive image of the country and can attract a great deal of foreign investment. Under these conditions, information technology development is a direct factor in the formation of national competitiveness. The presence of system problems in the development of this industry in Ukraine is a deterrent that slows down the involvement of the state in the process of attracting innovations, and increases the gap between Ukraine and highly developed countries on key social and economic indicators.

The aim of this paper is to analyze the current situation regarding information technology in Ukraine and to determinate new perspectives for its improvement in the short term. The subject of this study is economic relations, both internal and external, arising during normal operation of information and communication technology companies in Ukraine.

\section{Analysis of the latest research and publications}

The issue of information technology has already been extensively covered in the scientific literature.

Analysis of the problems of the industry was conducted by Ukrainian and foreign researchers. Such authors as P. Thorpe (1984), E. K. Clemons,

(c) Limited Liability Company "Consulting Publishing Company "Business Perspectives", 2017.

Sergiy Frolov, Doctor of Science (Economics), Professor, Sumy State University, Ukraine.

Anastasiia Hovorun, Master of Finance, Junior PR manager, De Novo LLC, Ukraine.

Myroslav Ostapenko, Ph.D. Student, Sumy State University, Ukraine.
S. P. Reddi, M. C. Row (1993) pay considerable attention to the impact of information technology on the economic system of the country. P. Thorpe (1984) conducts research of capabilities of information technology use in developing countries and concludes that their effects are positive despite the presence of certain restrictions. In his opinion the most important aspects of using information technology should be training, international cooperation and socio-political factors. E. K. Clemons, S. P. Reddi, M. C. Row (1993) put forward a hypothesis regarding companies opportunities to reduce coordination costs without increasing the risks of transactions by investing in information technology. B. Arora, Z. Rahman (2016) also explore the issue of investment in information technology. These authors analyzed existing investment strategies and identified the main factors that influence investment decisions in IT. By contrast, R. Benjamin, J. Blunt (1992) focuses on the study of innovation in the industry and prospects for its future development. In Ukraine, the research on this subject was conducted by O. M. Sasonets (2009), B. O. Khodakevich (2015), A. V. Katrenko, O. V. Pasternak (2014), N. V. Holyachuk, S. V. Ryhliuk (2014), A. Ye. Lytvyn (2011) and others. O. M. Sasonets (2009) examines the process of managing investments in information technology and analyzes the efficiency of of investment projecting in information technology, whereas N. V. Holyachuk, S. V. Ryhliuk (2014), S. V. Voitko, T. V. Sakalosh (2016) explore the theoretical aspects of information technology enterprises. A. Ye. Lytvyn (2011) studies the historical stages of development of information technology in Ukraine, and B. O. Khodakevich (2015) considers possible 
scenarios for the future. A. V. Katrenko, O. V. Pasternak (2014) thoroughly examine potential methods for attracting investment capital for the development of Ukrainian IT industry.

But according to the dynamics of technology development and the rapid pace of change in economic conditions in Ukraine (which are currently marked with a difficult economic and political situation), the topicality of improving the development of information technology here is very strong. However, there remain system problems that require an early solution.

\section{The main results of the research}

Information and communication technology is one of the most important factors stimulating economic growth and development of civil society, employment, greater competition and, consequently, overcoming the "digital gap". We can state the fact that the level of technological development determines not only the potential of the economy of the country and quality of life of its citizens, but also the role and place of this country in a global society, the scope and prospects for economic and political integration with the entire world (Resolution of the the Verkhovna Rada of Ukraine, 2016).
The information technology industry occupies an important place in the economy of Ukraine. The enterprises by type of economic activity "Information and Telecommunications" employed over 114,3 thousand economic entities of different ownership formsin 2015, including 13,3 thousand enterprises and 101 thousand individual entrepreneurs. Employees of these economic entities totaled 306,3 thousand people, which is about 3.5\% of the total number of persons employed in Ukraine (State Statistics Committee).

Gross domestic product (by production method) generated by economic entities in the sector of information and telecommunications in 2015 amounted to $6.73 \%$ (72 596 million UAH) of total GDP of Ukraine. A similar share of the sector in 2014 amounted to $4.88 \%$ (52 $724 \mathrm{UAH}$ ) (Fig. 1) (State Statistics Committee).

Thus, the share of information and communication technology in GDP structure tends to rise rapidly. This rate of growth exceeds the growth rate of nominal GDP, from which we can conclude that enhances it the role of the IT industry in the economic and financial system of Ukraine.

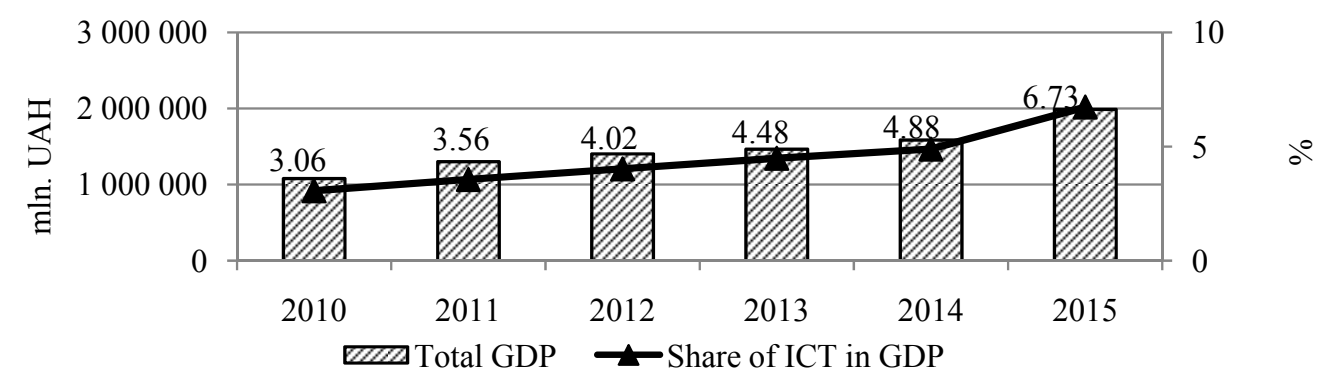

Fig. 1. Dynamics of total GDP and the share of ICT in it for 2010-2015 (State Statistics Committee)

This growth is ensured by the process of expanded reproduction, which is characterized by capital intensity and specific resource consumption. Based on that, we can adress the need to attract significant amounts of capital investment.

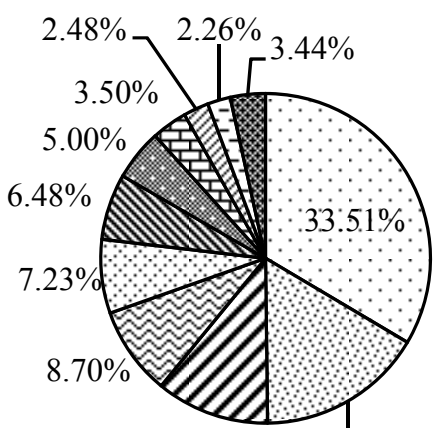

$11.11 \% \quad 16.30 \%$
Considering the structure of assimilated capital investments by economic activity types (Fig. 2), we find that information and communication technology industry ranks 4th. Only the respective sectors of industry, construction and agriculture precede it in that order.

๑Industry

๑Construction

Agriculture, forestry and fisheries

घInformation and Telecommunications

$\square$ Wholesale and retail trade; repair of motor vehicles and motorcycles

Transport, storage, postal and courier cervices

Public administration and defense; compulsory social insurance

BReal estate

Fig. 2. The structure of assimilated capital investments by economic activity types in 2015 (State Statistics Committee) 
An important source of capital investment is international investment funds attraction. Enterprises of the industry of information technology came in the first place by the dynamics of the annual growth of foreign direct investment in 2015, the volume of FDI at the end of 2015 amounted to 2308,7 $\mathrm{mln}$. US dollars, reaching $5.3 \%$ of total foreign investment (State Statistics Committee).
But, despite the presence of positive trends in the IT industry, there remain some system problems in this sector. Calculation of the index of investment attractiveness by the methodology of the European Business Association (Fig. 3) shows that the investment attractiveness of Ukraine is low and needs to take action regarding its improvement.

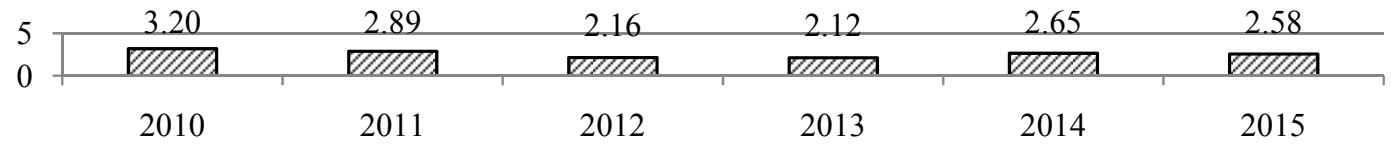

๑The index of investment attractiveness of Ukraine

Fig. 3. The index of investment attractiveness of Ukraine in 2010-2015 (European Business Association)

The number of highly qualified IT personnel leaving Ukraine in the years 2014-2015 was about 5 thousand people (Resolution of the the Verkhovna Rada of Ukraine, 2016). This weakens national industry and increases the gap in development between Ukraine and more highly developed countries of the world. Another problem concerning human capital is the obsolescence of education on information technology in public universities. This causes the need for further training and retraining of industry experts.

The excess in exports of information technology on the volume of sold goods and services in the industry (Table 1) shows the narrowness of the national market. In addition, significant amounts of outsourcing services are manifested in increasing the GDP of other countries by results of work of Ukrainian specialists.

Table 1. Ratio of exports and the total volume of produced goods and services in information technology industry in 2010-2015 (State Statistics Committee)

\begin{tabular}{|c|c|c|}
\hline Year & $\begin{array}{c}\text { Volume of sold in Ukraine goods and services in } \\
\text { information technology industry, mIn. UAH }\end{array}$ & $\begin{array}{c}\text { Volume ofexports of goods and services in information } \\
\text { technology industry, mln. UAH }\end{array}$ \\
\hline 2012 & 79354.9 & 1113530.6 \\
\hline 2013 & 80410.4 & 1477182.4 \\
\hline 2014 & 84103.6 & 1675551.7 \\
\hline 2015 & 100590.4 & 1585572.6 \\
\hline
\end{tabular}

From the above analysis, we can formulate a list of industry and identify a number of recommendations major system problems in information technology for their solution.

Table 2. System problems in the development of IT sector in Ukraine and and their possible solutions

\begin{tabular}{|c|c|c|c|}
\hline № & Problem & Essence & Possible solutions \\
\hline 1. & $\begin{array}{l}\text { Obsolescence and low } \\
\text { relevance of the state IT } \\
\text { education }\end{array}$ & $\begin{array}{l}\text { The level of preparation of IT specialists, the } \\
\text { list of specialties and training programs for IT } \\
\text { professionals at universities do not meet the } \\
\text { needs of industry in the global market of IT } \\
\text { products and services. }\end{array}$ & $\begin{array}{l}\text { - the introduction of public-private partnership in IT education; } \\
\text { - opening state grant programs to study in leading universities in } \\
\text { Ukraine and other countries; } \\
\text { - re elaboration of university programs with taking into account } \\
\text { recommendations of practitioners of the leading IT companies; } \\
\text { - government support for internship programs }\end{array}$ \\
\hline 2. & $\begin{array}{l}\text { The low level of investment } \\
\text { attractiveness of the country }\end{array}$ & $\begin{array}{l}\text { The low level of attractiveness to potential IT } \\
\text { investors and customers of high-tech } \\
\text { products and services. }\end{array}$ & $\begin{array}{l}\text { - stabilization of the political environment in Ukraine; } \\
\text { - creating a positive international image; } \\
\text { - reducing bureaucratization of business }\end{array}$ \\
\hline 3. & $\begin{array}{l}\text { Lack of state support for the IT } \\
\text { sector }\end{array}$ & $\begin{array}{l}\text { The lack of promotion of Ukraine as a } \\
\text { European high-tech hubby the state. }\end{array}$ & $\begin{array}{l}\text { - launching individual programs of state support for small, medium } \\
\text { and large IT companies }\end{array}$ \\
\hline 4. & $\begin{array}{l}\text { The prevalence of outsourcing } \\
\text { in the structure of IT services }\end{array}$ & $\begin{array}{l}\text { Outsourcing orientation of the executed } \\
\text { works determines the fact that most of the } \\
\text { added gross value remains abroad. }\end{array}$ & $\begin{array}{l}\text { - development of weighted tax and economic mechanisms of } \\
\text { transmission performed services abroad with the provision of social } \\
\text { support to workers within the legal framework Ukraine }\end{array}$ \\
\hline 5. & The narrow domestic market & $\begin{array}{l}\text { Low demand for the products on the domestic } \\
\text { market. }\end{array}$ & $\begin{array}{l}\text { - implementing programs for encouragement of using innovative } \\
\text { technology for companies of various industries }\end{array}$ \\
\hline 6. & $\begin{array}{l}\text { The need to import equipment } \\
\text { and technology }\end{array}$ & $\begin{array}{l}\text { There is no closed cycle of production of } \\
\text { computer and office equipment. }\end{array}$ & $\begin{array}{l}\text { - opening own closed cycle production of computer equipment in } \\
\text { conditions of international franchise }\end{array}$ \\
\hline 7. & $\begin{array}{l}\text { Leaving of highly qualified } \\
\text { personnel }\end{array}$ & $\begin{array}{l}\text { Increased competition for IT professionals } \\
\text { with other countries by offering them better } \\
\text { working conditions abroad. }\end{array}$ & $\begin{array}{l}\text { - enhance social protection of population; } \\
\text { - raising salaries; } \\
\text { - implementation of the national health insurance system }\end{array}$ \\
\hline
\end{tabular}


Table 2 (cont.). System problems in the development of IT sector in Ukraine and and their possible solutions

\begin{tabular}{|c|l|l|l|}
\hline № & \multicolumn{1}{|c|}{ Problem } & \multicolumn{1}{|c|}{ Essence } & \multicolumn{1}{c|}{ Possible solutions } \\
\hline 8. & $\begin{array}{l}\text { The imperfection of Ukrainian } \\
\text { legislation }\end{array}$ & $\begin{array}{l}\text { Instability and unpredictability of state and } \\
\text { legislative policy in business and IT. }\end{array}$ & $\begin{array}{l}\text { - stability and predictability of laws passed; } \\
\text { - enable the settlement of investment disputes involving the state in } \\
\text { international arbitration and enforcement of their decisions }\end{array}$ \\
\hline 9. & $\begin{array}{l}\text { Imperfect system of taxation in } \\
\text { IT sphere }\end{array}$ & $\begin{array}{l}\text { The tax system of Ukraine is one of the most } \\
\text { burdensome in the world, because it is } \\
\text { necessary to carry out a large number of new } \\
\text { tax-payments, requiring a significant } \\
\text { investment of time. Moreover, it ignores many } \\
\text { industry tax features of IT companies. }\end{array}$ & $\begin{array}{l}\text { - reduce the tax burden by reducing the list of mandatory payments; } \\
\text { improving conditions of taxation for performing renewal of fixed } \\
\text { assets and small business development }\end{array}$ \\
\hline 10. & $\begin{array}{l}\text { Uneven regional development } \\
\text { of industry }\end{array}$ & $\begin{array}{l}\text { The vast majority of IT enterprises is } \\
\text { concentrated in 5 major cities of Ukraine. }\end{array}$ & $\begin{array}{l}\text { - stimulating the formation of IT cluster in cities that are lagging } \\
\text { behind in terms of IT }\end{array}$ \\
\hline
\end{tabular}

Note: Amusan, Oyekunle (2016), Cabinet of Ministers Resolution (2016), Holyachuk, Ryhliuk (2014), Resolution of the Verkhovna Rada of Ukraine (2016), Sazonets (2009), Seeletse (2016), Shambare, Shambare (2016), Voynarenko, Dzhuliy, Yemchuk (2016)

To assess the feasibility of the implementation of measures to solve these problems, we will carry out scenarios modeling for information technology industry, using traditional methods of extrapolation and an improved method of constructing artificial neural network model.

The market volume of information and communication services is defined as GDP generated by industry of information and communications.
But given the instability of the hryvnia exchange rate to make forecasts, we will use output data from the State Statistics Committee website in local currency and the same data, but converted into US dollars by the weighted average annual rate of NBU. According to the forecasting carried out by software extrapolation, namely the determination of the trend line, graph dynamics of the ICT market will be as follows:

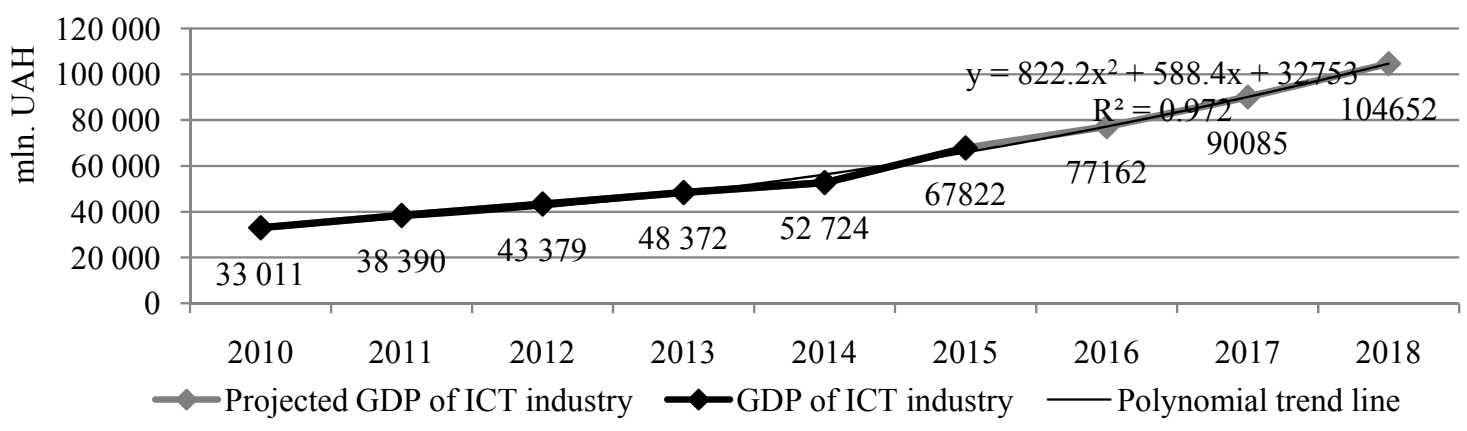

Fig. 4. Predictive value of IT market volume according to polynomial trend line in 2016-2018

Given the persistent tendency to increase in the volume of IT market in the national currency, the forecasted values were calculated based on available statistics by the polynomial approximation method naturally also show the expected growth. Construct a similar prediction using data in the US dollars.

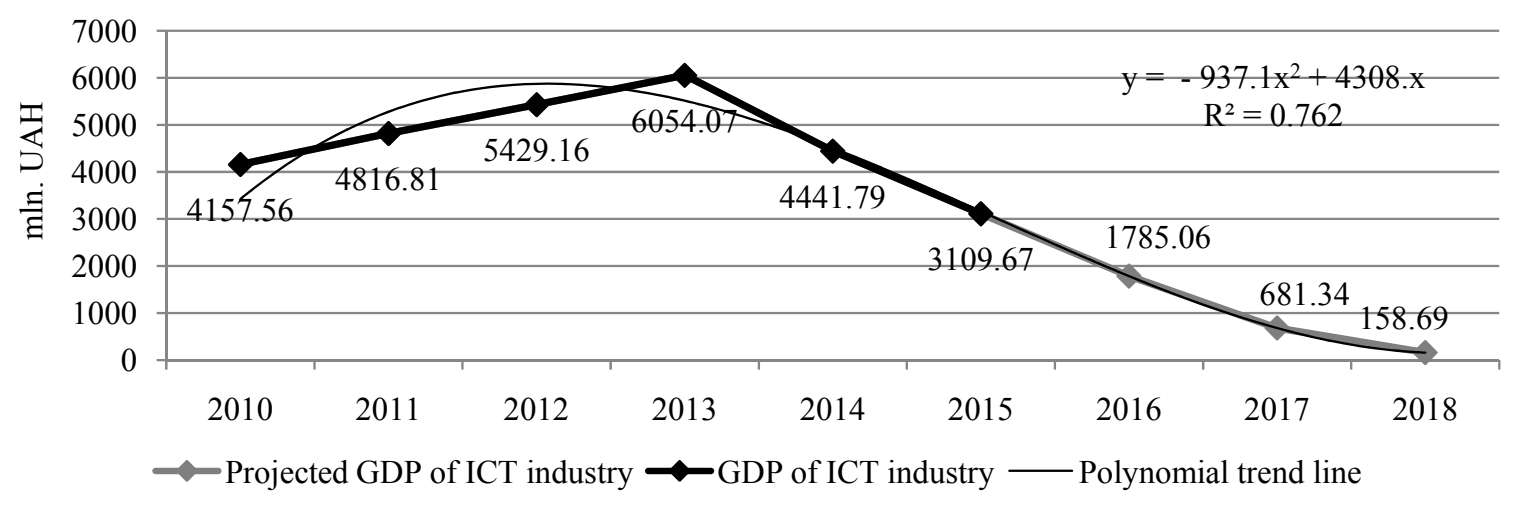

Fig. 5. Predictive value of IT market volume according to logarithmic trend line in 2016-2018

Having made numerous conversions of parameters in UAH into US dollars, we see that in 2014 and 2015, there was an extreme drop in the market volumes. In accordance with the initial data, the maximum value of coefficient of the determination has a polynomial trend line, for which $\mathrm{R}^{2}$ is 0.972 . 
That indicates a high level of compliance of the trend model with output data. The obtained equation of polynomial prediction has the form $\mathrm{y}=51,152 \mathrm{x}^{3}$ $937,12 x^{2}+438,4 x$. Substituting the required data into the equation, we get predictive value of GDP produced by the ICT sector in $2016-1785,06 \mathrm{mln}$. US dollars, in 2017 - $681,34 \mathrm{mln}$. US dollars, in 2018 $158,69 \mathrm{mln}$. US dollars. Interpreting the results, we see that, despite adequate coefficient of determination, achievement of such results is unlikely, since it is based only on steep fall of market and does not include all measures for economic recovery after 2014.

Performing trend forecasts using models in this case is very difficult, because it is impossible to identify certain trends or regularities. In this case, it will be appropriate to use the artificial neural network method. That is a mathematical model and its software and hardware implementation, based upon the principle of the operation of biological neural networks - networks of nerve cells of a living organism.

By calculating correlation and determination coefficients, we determined that the factors that carry the greatest influence on the IT market is GDP, exports, FDI volume and average salary in Ukraine. Thus, add the value of selected factors to the original data to build the model. This modeling is carried out by the add NeuroXL for Microsoft Office Excel.

Table 3. Artificial neural network model of the IT market in Ukraine

\begin{tabular}{|c|c|c|c|c|c|}
\hline Year & GDP, mIn. UAH & Exports, ths. USA dollars & $\begin{array}{c}\text { FDI, bln. USA } \\
\text { dollars }\end{array}$ & $\begin{array}{c}\text { Average salary, } \\
\text { UAH }\end{array}$ & $\begin{array}{c}\text { IT market volume, mln. USA } \\
\text { dollars }\end{array}$ \\
\hline 2010 & 1079346 & 11936316.7 & 44.8 & 2247 & 4157.56 \\
\hline 2011 & 1299991 & 14180342 & 50.3 & 2639 & 4816.81 \\
\hline 2012 & 1404669 & 14096178.1 & 55.3 & 3032 & 5429.16 \\
\hline 2013 & 1465198 & 14233226.1 & 57.1 & 3274 & 6054.07 \\
\hline 2014 & 1586915 & 11520850.7 & 45.7 & 3470 & 4441.79 \\
\hline 2015 & 1979458 & 9736654.2 & 43.4 & 4207 & 3109.670 \\
\hline
\end{tabular}

For comparison of estimated figures obtained by extrapolation forecasting method using a polynomial trend equation and by building an artificial neural network model, please refer to the results displayed on the chart.

As demonstrated, the forecast values obtained by using the trend line values and parameters calculated using artificial neural networks are somewhat different.

Analyzing the results, we can conclude that the achievement of forecast values obtained by constructing the artificial neural network model is more likely, since it considers hidden relationships and interdependencies.

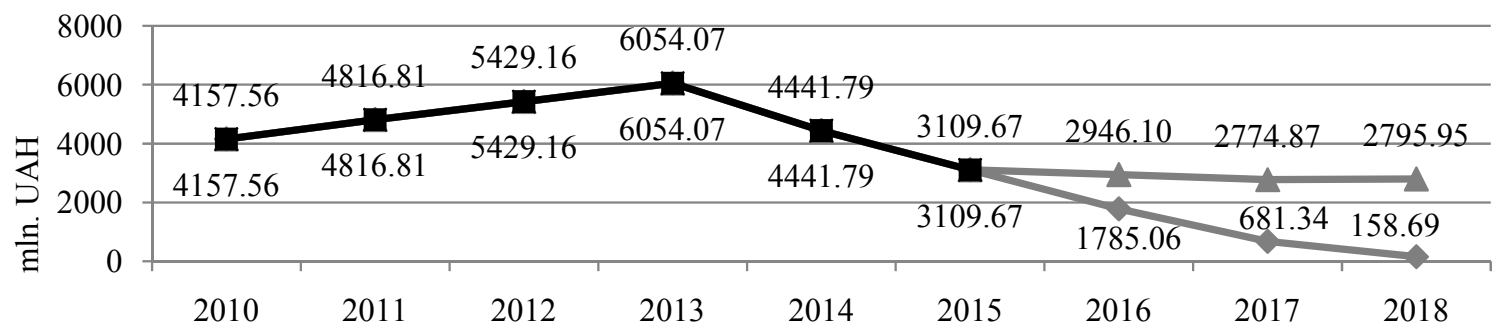

- Projected figures obtained by constructing artificial neural network model

$\sim$ Projected figures obtained by extrapolation forecasting method using a polynomial trend equation

$\rightarrow$ GDP of ICT industry

Fig. 6. Predictive value of IT market volume in 2016-2018

As a final confirmation of the effectiveness of the taxonomic indicator for actual figures of the IT proposed measures, we will use the method of market and the predicted values obtained using the taxonomic analysis, calculating the value of model of artificial neural network.

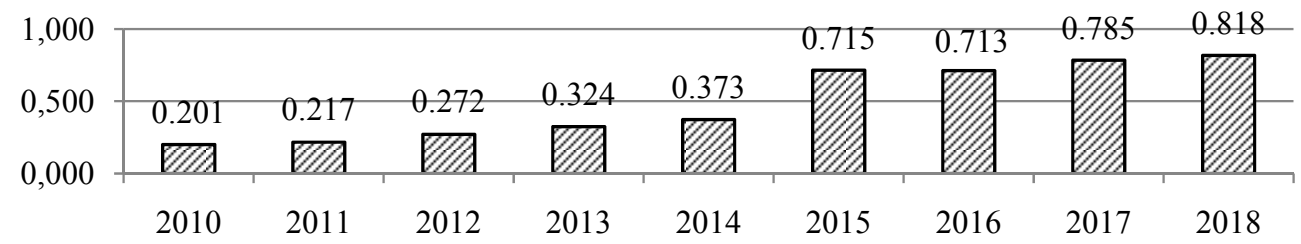

Fig. 7. Dynamics of taxonomic indicator in 2010-2018 
According to the taxonomy indicator graduation in 2010-2014, there was a low level of development of information technology in Ukraine. Beginning in 2015, rapid growth is evident. In 2015, the IT industry exhibited a high level of development. Given the calculated predicted value in 2016 and 2017 , it is expected to maintain this high rate of development and to reach the highest level in 2018.

\section{Conclusion}

Information and communication technologies in Ukraine is an important backbone industry, which is rapidly growing and currently generates about $6 \%$ of GDP. An important factor for stimulating further development is the attraction of international investments, which contribute to the modernization of production, improvement of the professional skills of employees, introduction of international technology and business standards.

Despite all the positive trends in information technology, Ukraine is characterized by a number of overall and specific problems, the solution of which should be a priority for creating a favorable economic and financial climate in the country and improving the living standards. The use of a number of measures to solve system problems will lead to a gradual recovery of the industry and achievement of a high level of development, which is reflected by the prediction based on constructing a model of artificial neural network and by the calculation of a taxonomic indicator.

\section{References}

1. Amusan, L., \& Oyekunle, O. A. (2016). Conceptualizing innovationmanagement development through organizational learning in the publicservice: any lessons for developing states? Problems and Perspectives inManagement, 14(3-1), 266-275. doi: 10.21511/ppm.14(3-1).2016.13

2. Arora, B., \& Rahman, Z. (2016). Information technology investment strategies: a review and synthesis of the literature. Technology Analysis \& Strategic Management, 28(9), 1073-1094.

3. Benjamin, R. I., \& Blunt, J. (1992). Critical IT issues: The next ten years. Sloan management review, 33(4), 7.

4. Cabinet of Ministers Resolution № 349 from 06.07.2016. (2016). The development strategy of high-tech industries by 2025.

5. Clemons, E. K., Reddi, S. P., \& Row, M. C. (1993). The impact of information technology on the organization of economic activity: The "move to the middle" hypothesis. Journal of management information systems, 10(2), 9-35.

6. Holyachuk, N. V., Ryhliuk, S. V. (2014). Investment in the information technology. Journal of Khmelnytsky National University, 5(1), 116-122.

7. Katrenko, A. V., Pasternak, O. V. (2014). System aspects of investing in information technology. Journal of National University "Lviv Polytechnic", 1, 402-411.

8. Khodakevich, B. O. (2015). Prospects for the development of national IT sector. Economy and government, 8, 121-125.

9. Lytvyn, A. Ye. (2011). Features of Information Technology industry. Recent economic problems, 11(125), 300-307.

10. Resolution of the Verkhovna Rada of Ukraine from the 31.03.2016. (2016). On recommendations of parliamentary hearings on «Reform of Information and Communication Technologies and Development of Ukraine's information space». Bulletin of Verkhovna Rada, 17, 191.

11. Sazonets, O. M. (2009). Determination of the effectiveness of of investment projecting in information technology. Economy and region, 4(23), 148-151.

12. Seeletse, S. M. (2016). Information and communication technology asa primary tool for Sefako Makgatho Health Sciences University's statisticsand operations research business. Problems and Perspectives inManagement, 14(3), 115122. doi: $10.21511 / \mathrm{ppm} .14(3) \cdot 2016.12$

13. Shambare, R., \& Shambare, K. (2016). The adoption of tablet PCs by South African college students: an application of the technology acceptance model. Problems and Perspectives in Management, 14(1), 23-29. doi: 10.21511/ppm.14(1).2016.03

14. The official website of European Business Association. Retrieved from http://eba.com.ua/uk/press-and-media/pressroom/indices/investment-attractiveness-index

15. The official website of the State Statistics Committee of Ukraine. Retrieved from http://www.ukrstat.gov.ua

16. Thorpe, P. (1984). The impact of new information technology in the developing countries. Information Scientist, 8(5), 213-220.

17. Voitko, S. V., Sakalosh, T. V. (2007). Market information and communication technology: structure and analysis. Journal of National University "Lviv Polytechnic", 594, 384-392.

18. Voynarenko, M., Dzhuliy, V., \& Yemchuk, L. (2016). Development ofinformation systems and modeling of their implementation in thebusiness. Problems and Perspectives in Management, 14(3), 102-107. doi: 10.21511/ppm.14(3).2016.10 